Capítulo 10 



\title{
Carisma, símbolo y rito de liberación y sanación: el caso del padre Pacho
}

\author{
Esneider Claros Castro, O. P.
}

\author{
Cada noche debo salir a pelear \\ contra un espíritu malvado \\ que, valiéndose de \\ disfraces - perro, grillo, \\ nube, lluvia, vago, \\ ladrón- trata de \\ infiltrarse en la ciudad \\ para estropear la vida humana \\ sembrando \\ la discordia. \\ A pesar de sus disfraces yo \\ siempre lo descubro \\ y lo espanto. \\ Nunca ha conseguido engañarme \\ ni vencerme.
}

La exorcista. Mario Vargas Llosa

Este capítulo es un trabajo etnográfico. Recrea el rito de sanación y liberación que realiza el sacerdote dominico fray Luis Francisco Pardo ${ }^{1}$, O. P. todos los sábados del mes en la pequeña ermita del Colegio Jordán de Sajonia de Bogotá, D. C. El

* Decano de la División de Ciencias Sociales. Correo electrónico: esneiderclaros@usantotomas.edu.co

1 El padre Pacho nació en Chiquinquirá, 81 años atrás. Sacerdote dominico, ordenado en 1962 e iniciado en la labor carismática en 1986, por monseñor Alfonso Uribe Jaramillo, precursor en Colombia del Movimiento de Renovación Católica. Por su parte, monseñor Alfonso Uribe Jaramillo nació en Nariño el 6 de febrero de 1994, y murió en La Ceja, Antioquia, el 7 de julio de 1993. En 1928 ingresó al Seminario Mayor de Medellín, y se ordenó sacerdote el $1 .^{\circ}$ de noviembre de 1937. Luego se trasladó a Canadá, a especializarse en teología. De regreso al país, fue nombrado rector del seminario donde se había ordenado, y en 1946 fue nombrado canónigo del Capítulo Metropolitano. En 1953 dejó estos dos cargos para trasladarse a Roma, donde participó en la Fraternidad Sacerdotal de esa ciudad. En 1954 fue nombrado párroco de Sonsón, tres años más tarde, y, creada la Diócesis de Sonsón-Rionegro, fue nombrado vicario general de esta. Su vida espiritual en 
rito comprende tres momentos: la oración, la eucaristía y el rito de sanación, al que asiste un gran número de creyentes. Los acontecimientos rituales que realiza el padre Pacho están enmarcados en el movimiento de Renovación Carismática Católica, cuyo emblema del Espíritu Santo, junto con las imágenes de Jesús y María Virgen, se encuentra en la pequeña capilla.

Mientras subía por el último repliegue de la cuesta - en dirección a los cerros orientales - que finalmente me condujo al Colegio Jordán de Sajonia, recordé, entonces, el pasaje del evangelio de Marcos en el que Jesús sana a un muchacho endemoniado. En este he venido pensando desde el día que me fue dado escribir un texto en el que diera cuenta del método etnográfico, y decidí hacerlo en torno al rito de sanación, liberación o exorcismo que realiza, todos los sábados, fray Luis Francisco Pardo O. P., "Pacho”, en la capilla del Colegio Jordán de Sajonia, propiedad de los padres dominicos.

La ermita del Colegio Jordán de Sajonia es una pequeña aula de clases acondicionada para fines religiosos. El ritual inicia desde las siete de la mañana, y se prolonga hasta las horas de la tarde; comprende una tríada de momentos que inicia con la oración, seguida de una extensa eucaristía, y alcanza el punto más alto, en horas de la tarde, con el evento de liberación o exorcismo. De cada uno de ellos, incluido un análisis final, daré cuenta en las líneas que siguen.

\section{El santo rosario y la invocación a los ángeles}

Son las siete de la mañana. Los creyentes oran. Una mujer de unos 40 años, aproximadamente, dirige, desde el costado derecho del altar, la oración. Los primeros feligreses se persignan siguiendo sus indicaciones. Acto seguido, rezan el credo, un padrenuestro, tres avemarías — por la fe, la esperanza, la caridad- . La imagen de María aparece en la ermita a través de la oración, los fieles rezan con fervor, creen sentir su presencia; es la expresión más sacra del santo rosario, y su presencia forma parte de los planes de Dios; por ello, los rezos se sienten e inundan

\footnotetext{
el seminario la combinaba con el cultivo de huertos y el cuidado de jardines. En 1960, mientras el seminario crecía, inició su labor de formación sacerdotal con 47 estudiantes. El 4 de agosto de 1963 fue nombrado obispo auxiliar de Cartagena, y quince días después ordenó a los primeros sacerdotes, diáconos y subdiáconos en el Seminario Cristo Rey. En 1964, monseñor Uribe Jaramillo fue invitado por el papa Pablo VI al Concilio Vaticano II, y tres años más tarde, el mismo papa lo nombró obispo de la Diócesis de Sonsón-Ríonegro. En 1972 fue nombrado vicepresidente de la Conferencia Episcopal de Colombia, por un periodo de tres años. En 1981 fundó el Seminario Misionero del Espíritu Santo, y desde 1983 se dedicó a promover, nacional e internacionalmente, la Renovación Carismática Católica, entre sacerdotes y párrocos, con lo cual se convirtió en uno de los eminentes miembros de este movimiento.
} 
el lugar de un olor monacal ${ }^{2}$. Después, la mujer hizo una inflexión en su voz, para decir: “¡Gloria al Padre y al Hijo y al Espíritu Santo!” Los crédulos repiten al unísono: "Como era en el principio, ahora y siempre, y por los siglos de los siglos. Amén...”. Esto lo hacen tres veces, siempre siguiendo la instrucción de la guía. No hay rastros del padre Pacho.

La bruma de las primeras horas de la mañana desciende de la montaña, se posa sobre el cielo de la pequeña capilla, mientras el frío entra por las pequeñas ranuras del templo. La mujer sigue su perorata sacra:

¡Oh Dios!, tú único Hijo nos ha conseguido con su muerte y resurrección los bienes de la salvación eterna: concédenos que, venerando estos misterios en el Santo Rosario de la Virgen María, imitemos aquello que contienen y obtengamos aquello que prometen. Por Jesucristo nuestro Señor.

“¡Amén!”, dicen los fieles al unísono. Los minutos pasan, a medida que los rezos de los misterios gozosos, con sus padresnuestros y avemarías respectivos, son realizados. Las dieciocho pequeñas bancas - alineadas en tres filas-, en las que solo caben tres personas sentadas, empiezan a ser ocupadas en su totalidad. Terminado el santo rosario, la mujer (de quien supe después que se trataba de una de las fieles que asiste con regularidad a la ermita, y a quién el padre Pacho le ha encomendado la labor de rezar el santo rosario) reparte entre los fieles unos cuadernillos en los que están las oraciones y alabanzas que, siempre bajo la guía de ella, deben seguir los feligreses. Después, los hombres y mujeres reunidos en el lugar rezaron las siguientes oraciones: suplicio ardiente a los santos ángeles, oración a san Miguel, san Rafael Arcángel, letanías a los santos ángeles, invocación al santo ángel de la guarda. Es muy significativa la invocación a los ángeles en el rito que se realiza en la ermita del Colegio Jordán de Sajonia, pues san Miguel, en muchas religiones, incluida la católica, es el jefe de los ejércitos de Dios, y el encargado de frustrar los planes de Lucifer; por ello, es representado en el arte como un ángel con armadura que amenaza con una espada al demonio. San Rafael, por su lado, es el arcángel encargado de sanar las enfermedades y las heridas de los hombres, y el ángel de la guarda es el ángel custodio enviado por Dios para proteger a cada hombre durante su vida.

Ahora bien, la invocación a los ángeles no hubiera tenido sentido para mí, de no haber sido porque el 24 de septiembre de 2014 sostuve una conversación

2 El culto mariano que han iniciado los fieles constituye uno de los momentos centrales en el Movimiento de Renovación Católica. Su origen, aunque se remonta a los primeros años de la Iglesia primitiva, fue renovado en el Concilio Vaticano II, a través de la Constitución Dogmática Lumen Gentium, en la que María aparece como "Madre del Salvador", e incluida en los Misterios de la Iglesia. Después del Concilio, el papa Pablo VI publicó el Marialis cultus, una exhortación apostólica que conminaba a los fieles a desarrollar correctamente el culto a la Virgen. Juan Pablo II también promovió el culto a María, hasta el punto de consagrar su propio mandato a ella. 
con el padre Pacho; allí me reveló que siempre le tuvo miedo a los asuntos del demonio, creía que la lucha contra El Maligno solo era cosa de los santos y los apóstoles, hasta que asistió a un retiro, en 1986, en La Ceja, con monseñor Alfonso Uribe Jaramillo. Ese día, el padre se inició en la labor carismática, un hecho trascendental en la vida sacerdotal que marcó para siempre su labor en la orden a la que pertenece. Me dijo que el último día del retiro, recibió de manos de monseñor el regalo de una de sus obras: Ángeles y demonios. Monseñor Uribe Jaramillo expresa aquí la importancia de los ángeles o "espíritus buenos" en la lucha contra Satanás, y la fuerza que estos han tomado desde el Movimiento de Renovación Católica:

La Renovación Espiritual Carismática nos está haciendo descubrir la presencia del Espíritu Santo en la Iglesia y en cada uno de nosotros, y las maravillas de su poder. Nos está mostrando también la realidad y la fuerza de los espíritus malignos, y ahora empieza a descubrirnos de nuevo con gran claridad la existencia de los espíritus angélicos y el papel providencial que, por orden de Dios, deben desempeñar en favor nuestro. (Uribe, 1995, p. 45)

Mientras hablábamos, el padre recordó la insistencia que monseñor le hacía a él, y a otros sacerdotes que asistieron al retiro en 1986, sobre la importancia de la oración a María y a los ángeles para luchar contra Satanás, y afirmó: "Desde que lucho contra El Maligno, siempre invoco la presencia de los ángeles, y también la de la Virgen María”.

Aunque hasta este momento, el padre Pacho no ha hecho su presencia en la ermita, es su rito el que se realiza en la pequeña capilla. Por ello, la gracia de los ángeles que une a Cristo con el Espíritu Santo es la protección, guía e intercesión ante Dios en favor de los feligreses que han llegado al lugar. El evento de la oración terminó con Alabaré, el cántico religioso para alabar a Dios ${ }^{3}$. Alabaré también es utilizado por los pentecostales y protestantes, entre otras congregaciones religiosas, en sus celebraciones litúrgicas, pues posee la facultad de "mover" a los feligreses - tiene un efecto emocional en ellos-. La acción que describe el verbo "mover" es uno de los aspectos centrales en las celebraciones religiosas: logra que los feligreses experimenten sentimientos de filiación, cercanía, piedad, humildad, fe, entre otros, y esa es la razón principal de su entonación. Mientras los fieles cantan, siempre al unísono, aparece el padre Pacho, con su hábito beige; camina por el centro del recinto en dirección al altar, saluda y estrecha las manos de algunas de las almas que se habían dado cita en lugar. Estas se lanzan sobre él como si el solo roce con el sacerdote pudiera sanarlos. Son las 9:00 a. m.

3 Alabar a Dios es un mandato que aparece en la Biblia en más de trescientas oportunidades; el acto constituye acciones de gracias, es decir, altas prioridades espirituales que los feligreses, reunidos en la ermita, confieren a Dios. 


\section{La santa misa para la sanación de los enfermos}

El padre está detrás del altar. De rodillas, ora con fervor ante los pies de una gran cruz de madera, en la que yace un pequeño Cristo. Los feligreses cantan Muévete en mí. Este cántico, proveniente de las expresiones religiosas cristianas, y usado por otras congregaciones religiosas, entre ellas la católica, también posee, como Alabaré, el efecto de "mover" las emociones de los feligreses, al tiempo que con su entonación se mueve la presencia del espíritu de Dios por toda la ermita. Esto solo sucede en el plano de lo simbólico.

Muévete en mí hace emerger la imagen, hasta ahora ausente, del Espíritu Santo. Al costado derecho del altar, cinco personas ${ }^{4}$ - dos mujeres y tres hombres-, la "guardia personal", como el mismo padre Pacho les llama, por la ayuda que él necesita para luchar contra El Maligno, también acompañan los cánticos sacros. Cada uno de ellos, por turno, se acerca al padre, se arrodilla con él, el presbítero le susurra algo al oído, le unge los sentidos, impone las manos y lo bendice; luego, regresa a su lugar. La acción de ungir e imponer las manos tiene un significado particular en todo el rito que realiza el padre Pacho, pues al describir con su dedo pulgar la señal de la cruz sobre la frente, y colocarle las manos sobre la cabeza pone en las manos de Dios, en su presencia, a cada una de las personas que integran su "guardia personal".

El trabajo de la guardia personal del padre Pacho es muy significativo. Conforma, en total, un grupo de diez personas, que se dan cita en la ermita todos los sábados, son ungidos por el padre antes de iniciar su labor, oran, cantan, rezan durante la oración del santo rosario y la misa de sanación. Pero lo más llamativo ocurre bien entrada la tarde, cuando se inicia el rito de liberación, pues se ubican al costado derecho del pequeño altar, tienden una cortinita amarilla desde el techo hasta el piso, entre la columna y la pared oriental que sostiene el lugar, se hunden tras de ella, y empiezan a prepararse. Luego, emiten movimientos impropios, como si sus cuerpos no les pertenecieran: se tocan el pecho, las costillas, la cabeza, y se dicen cosas al oído, inentendibles entre ellos. Pero lo que más sorprende es que, sin dejar un solo instante sus movimientos trémulos, emiten unos sonidos guturales infernales, gritan, gimen, se ríen diabólicamente, producen voces cavernosas y algunos hablan otras lenguas. Cuando les pregunté por el origen de estas voces y lenguas, no supieron dar razón. Estos son signos de posesión.

4 En total son diez personas las que constituyen la "guardia personal" del padre (el día que presencié el rito que se describe solo asistieron cinco de ellos). El padre me dijo, el día que lo entrevisté, que todos habían sido liberados y sanados por él, y ahora le ayudan a luchar contra los demonios. 
Algunos feligreses también realizan esos movimientos involuntarios; algunos se desploman y pierden el conocimiento; ríen, gimen, se quejan..., mientras el Padre ora, seguido por el unísono de las voces de los demás feligreses. Al percibir un signo de posesión en uno de los asistentes, los miembros de la guardia salen de detrás de la cortinita en busca de él, lo conducen hasta el lugar donde han estado, y se vuelven a hundir detrás de ella, siempre con la anuencia y la compañía del padre Pacho. Allí rodean al poseso, y lo sostienen mientras el padre lo unge y le habla cosas al oído; la guardia personal toca al sufrido, le punzan con el puño cerrado las costillas, el pecho, el estómago. Entre tanto, el enfermo emite gritos cavernosos y movimientos corporales involuntarios hasta que se desploma. El padre sigue orando en voz alta por todo el lugar, mientras su guardia personal se encarga de reanimar al poseso.

El padre Pacho camina entre los pasillos que separan las pequeñas banquetas. Está buscando algo, mira a los feligreses, los abraza, los toca, sigue en la búsqueda. Regresa al altar. Parece que no encontró lo que buscaba. Su movilidad por la ermita es uno de los elementos centrales de su poder carismático - por lo menos así lo creen los fieles-. Los fieles no logran comprender lo que busca, él está tratando de identificar a los fieles que lo han visitado el martes y el jueves anterior en el Convento de Santo Domingo; allí los recibe y se entera de sus sufrimientos. Aunque la impresión de los fieles es que el padre está tratando de identificar los signos por los cuales se manifiesta el demonio en los posesos, lo que realmente hace es identificarlos, reconocerlos y valorar su dolor.

Si bien este trabajo solo se refiere a los eventos observados el sábado 27 de septiembre de 2014, lo cierto es que el ciclo ritual del padre Pacho constituye una tríada de momentos que se inicia el día martes, cuando impone sus manos sobre los enfermos, y los coloca ante la presencia de Dios, en el Convento de Santo Domingo; continúa el jueves, también en el Convento, cuando ora junto a ellos, y concluye el sábado, en la ermita del Colegio Jordán de Sajonia.

Luego, levanta sus manos, mira hacia arriba, y ora:

Este es mi deseo: que los que me confiaste estén conmigo donde yo estoy y contemplen mi gloria, la que me diste, porque me amabas, antes de la fundación del mundo. Padre este es mi deseo: que los que me confiaste estén conmigo donde yo esté y contemplen mi gloria, la que me diste porque me amabas antes de la creación del mundo. Padre santo, Padre justo, si el mundo no te ha conocido, yo te he conocido y estos te han conocido y han conocido que tú me has enviado". Este es mi deseo: que los que me confiaste estén conmigo donde yo estoy y contemplen mi gloria, la que me diste porque me amabas. A ti también te tiene preparada, porque te ama antes de la fundación del mundo. Padre santo, si el mundo no te ha conocido, yo te he conocido y estos han conocido 
que tú me has enviado. Esto es lo más bello: les he dado a conocer tu nombre para que el amor que me tenías esté en ellos como también yo estoy en él.

Esta predica es una construcción personal, es un juego de palabras edificado a lo largo de su experiencia sacerdotal, que denota un diálogo personal con el Nazareno. Los enfermos son testigos mudos de la conversación entre el abajo y el arriba, entre lo humano y lo divino, entre El Padre y Jesús y, aunque lo escuchan, sus oídos no son la fuente para la comprensión del diálogo entre los dos interlocutores. Un aire sacro cubre la humanidad del presbítero, se eleva por encima de su cabeza, de sus feligreses, y en los rostros de los enfermos aparece una sensación de fe, credulidad y esperanza sustentadas en la idea de que el diálogo del padre Pacho con Jesús puede sanarlos. El padre deja de orar, pasa una tierna mirada por todo el lugar, y se dirige a su rebaño con sus propias palabras:

A Jesús, su Padre lo amaba desde la eternidad, y a ti te amó con amor eterno, "Con amor eterno te amé" — dice el profeta-. ¿Han pensado en esto? ¿Quién me puede a mí hablar del amor de Jesucristo? ¡Mira la cruz, hermano, fue por ti, porque te amaba! ¿Tú nunca has pensado en eso? Por eso, permítanme volverlos a Jesús, ni para desear el cielo que nos tiene prometido, ni tampoco el infierno tan temible, sino para dejar de ofenderlo. Algunos se mueren por deseos y temores... de estrés. Tú me mueves, Señor, muéveme a mi verte clavado en esa cruz: destrozado, herido, adolorido... ¿Has contemplado el rostro de Cristo adolorido? ¿Has contemplado sus llagas? ¿Su corazón abierto?

Los fieles asienten ante el llamado del sacerdote:

Hermanos, no han conocido a Jesucristo, porque si lo conocieran, distinta sería su suerte. Lo mejor es que tengamos el amor de Jesús, esto es lo más bello, porque el amor que me tenías, el amor que el Padre le tenía a Jesucristo, está en ti como en mí y Él permanezca.

El reconocimiento de Jesús es el símbolo sanador. Él puede sanar a los enfermos, no importa cuál es el mal que se padece, pero también su desconocimiento es la causa por la que se está enfermo. El Padre lo sabe y se lo hace saber a los fieles cuando dice:

¿Y sabes también por qué tienes que alegrarte? Porque eres pecador. Y cuando sabemos que somos pecadores, y lo reconocemos, y no hacemos alarde, es cuando él viene en ayuda de nuestra debilidad. "Me han azotado y golpeado. ¿Quién me apartará esta carne mortal? Mi gracia te basta”, le dijo Jesús. Que en la debilidad se fortalece. Ese es nuestro pecado, es nuestra pequeñez, es nuestra miseria humana. Entonces, hermanos, basta que crean en él, y eso los salve. 
Vamos a colocar aquí nuestras penas, nuestras alegrías, nuestras tristezas, todo aquello que no es de Jesús, nada de tristeza, quién dijo de estar tristes. Un santo triste es un triste santo. Un hijo de Dios no puede estar triste: Pablo se encontraba en su dolor para que reinara en él el poder de Cristo. Entonces, mis hermanos, coloquemos nuestras penas, con tu corazón, con tu alma, con tu corazón herido, tu alma rota, tu cuerpo enfermo, lo que traigas, pero te lo entrego, Señor, y te lo entrego, porque Él, solo Él puede sanarlo, porque Él puede quebrarlo.

Entonces, colocamos aquí nuestro corazón herido, el ánima rota, el corazón enfermo, las penas que nos agobian, la situación económica, espiritual, física, moral, todo, pues Él lo sabe mejor que tú. No vayas a decir nunca: “¿Dónde está Dios?”, eso es una blasfemia. Él nunca te olvida, Él no se olvida de ti. Cuando el pueblo agobiado, extenuado - óiganme bien-, extenuado por su infidelidad, por su ingratitud, decía el Señor de lo alto. Esclavizado, el Señor me ha abandonado, y el Señor me decía: "Podrá una madre olvidarse de su hijo, podrá una madre desentenderse del hijo de sus entrañas, pues aunque la madre te olvidara, yo nunca te olvidaré".

Lo anterior constituye un juego retórico. El padre modula, adopta una postura corporal de sumisión, encoje sus hombros, y hace énfasis en determinadas expresiones: "Ese es nuestro pecado, es nuestra pequeñez, es nuestra miseria humana. Entonces, hermanos basta que creas en Él y eso te salve"; "Entonces, mis hermanos, coloquemos nuestras penas, con tu corazón, con tu alma, con tu corazón herido, tu alma rota, tu cuerpo enfermo, lo que traigas, pero te lo entrego, Señor, y te lo entrego, porque Él, solo Él puede sanarlo, porque Él puede quebrarlo" y "Entonces, colocamos aquí nuestro corazón herido, el ánima rota, el corazón enfermo, las penas que te agobian, la situación económica, espiritual, física, moral, todo, pues Él lo sabe mejor que tú".

Pero también existe un cambio de voces en la súplica del Padre, es un juego polifónico que emociona a los feligreses, los mueve, cuando dice: "Me han azotado y golpeado" “Quién me apartará esta carne mortal?" "el Señor me ha abandonado y el Señor me decía: 'Podrá una madre olvidarse de su hijo, podrá una madre desentenderse del hijo de sus entrañas, pues aunque la madre te olvidara, yo nunca te olvidaré". El cambio de voces en la súplica retórica del Padre lo coloca, algunas veces, en franco diálogo con los feligreses, y otras, en un diálogo directo con Jesús y con Dios, pues el fin de este intercambio de lugares polifónicos es avivar las emociones, los sentimientos y la fe en los asistentes.

Las palabras del padre Pacho empiezan a hacer efecto. Su guardia personal empieza a temblar: son movimientos eléctricos, impropios, acompañados de gritos y gemidos sobrenaturales, suerte de éxtasis que solo está en quienes sirven al padre en su lucha contra el mal. Luego, algunos de los feligreses realizan gestos, como si 
estuvieran poseídos por algo, acaso por alguien. Los gestos, gritos y gemidos de la guardia personal del padre Pacho comprenden estados alterados de la conciencia (a los que se han referido algunos autores, como Mircea Eliade y Mary Douglas, entre otros), pues luego de realizar movimientos impropios, salen fortalecidos para luchar, junto al Padre, contra los endemoniados. Estas alteraciones de la conciencia permiten que las personas se desconecten de su propia realidad, entren en contacto con otra, distante de los umbrales de la razón, y salgan fortalecidos para ayudar a otros.

La pequeña ermita del Colegio Jordán de Sajonia se ha convertido en un pabellón de gente trémula. Las emociones se han hecho presentes en el lugar, los rostros de los feligreses describen expresiones de fe, credulidad y esperanza; estas son emociones que el rito del padre ha logrado sacar a luz. El padre habla con mayor fuerza. Nuevamente, pasa revista por todo el lugar, identifica algunos signos demoníacos en algunos feligreses, y continúa con su sermón. El 24 de septiembre le pregunté al padre: “¿Cómo sabe usted cuando alguien está endemoniado?" En esa oportunidad me dijo: "Aunque son muchos los signos con los cuales se manifiesta el demonio, hay uno muy importante, y es que el que está endemoniado no puede sostenerme la mirada".

Vuelve al altar, apresura la comunión, el Cuerpo y la Sangre de Cristo se hacen presentes; algunos feligreses se desploman mientras el padre Pacho eleva el Cuerpo de Cristo a las alturas; otros gimen, lloran, gritan, se lamentan. Una minoría sigue con los temblores extremos. Tiempo después, el presbítero bendice a sus fieles y los conmina a ir en paz: "El Cuerpo y la Sangre de Jesús sea para vosotros, para quienes lo puedan recibir. Salud del alma y del cuerpo, y remedio y medio para merecer y tener la vida eterna. Por Jesucristo, nuestro Señor. Amén”. En la liturgia católica, el cuerpo y la sangre de Cristo constituyen la presencia real de Dios. Son las 12:30 del mediodía.

\section{Liberación y exorcismo}

La guardia personal del padre Pacho ha tendido una cortina entre una columna y la pared oriental de la ermita, para luego ocultarse detrás de ella. El padre está dispuesto. Camina por el pabellón de los enfermos —que, en últimas, es en lo que ha quedado convertida la pequeña ermita-, se desplaza con propiedad por todo el lugar, y sigue buscando algo en los rostros de sus fieles. Él es consciente de su poder carismático, así como los oprimidos, y por eso estos se le abalanzan. Habla de la importancia de la oración para el momento que sigue, de la fe; por ello, conmina a los feligreses a cerrar los ojos y a pedirle con fervor a los ángeles, a la Virgen y a Jesús. Acto seguido, los tranquiliza: 
No se preocupen, a partir de este momento habrá gente que grite, que se cae, que brinca y salta. Tú, en tu oración. Si allá a mi compañero le salta el demonio, tú, en tu oración, pidiéndole al Señor que tenga misericordia, confiando nada más, y verás lo que el Señor te va a sanar.

Sanar es un don, es la estructura central del carisma del padre Pacho. Luego le escuché decir, con mucha ternura: "Jesús mío, 'pelicano amoroso". El pelicano es el animalito que se saca la comida del buchecito para alimentar a su cría".

El presbítero dominico ha usado una metáfora para darle a entender a su rebaño que Jesús se sacó del alma lo más grande: "su amor, su cuerpo, su amor se hizo pan y nos la entregó. Jesús alimenta con su propio cuerpo, y no solamente su cuerpo, sino con su vida, su divinidad". Ahora bien, la alusión al "pelicano" es una expresión que el padre Pacho ha tomado en préstamo de Tomás de Aquino, en tanto que "amoroso" es una invención propia. Cosa comprensible, pues fray Luis Francisco Pardo pertenece a la misma orden a la que perteneció el Aquinate. Tomás de Aquino hace mención al "pelicano" en su Himno del Adorote Devote: "Señor Jesús, Pelícano bueno, límpiame a mí, inmundo, con tu Sangre, de la que una sola gota puede liberar de todos los crímenes al mundo entero" (De Aquino, 1993, p. 71).

"Ahora, todos", dice el padre, y los fieles lo siguen al unísono:

Alma de Cristo, santifícame.

Cuerpo de Cristo, sálvame.

Sangre de Cristo, embriágame.

Agua del costado de Cristo, lávame.

Pasión de Cristo, confórtame.

¡Oh, buen Jesús!, óyeme.

Dentro de tus llagas, escóndeme.

No permitas que me aparte de $\mathrm{Ti}$

Del maligno enemigo, defiéndeme.

A la hora de mi muerte, llámame.

Y mándame ir a Ti

Para que con tus santos y tus ángeles te alabe y te bendiga.

Por los siglos de los siglos. Amén.

El padre conmina a sus feligreses a hacer esta plegaria una, dos, tres, cuatro y cinco veces. Cada una de ellas se repite con mayor fervor que la anterior. El padre 
no se detiene, sigue con mayor fortaleza y entusiasmo sus súplicas, no se muestra agotado ni exhausto, su avanzada edad no es óbice para no luchar contra la enfermedad, el mal y el Maligno. Los fieles cierran sus ojos y siguen atentos a la voz del sacerdote. El padre está en los zapatos de Jesús, es el juego retórico polifónico al que me ya me referí:

El que come mi cuerpo y bebe mi sangre tiene vida eterna y yo le resucitaré el último día. Mi carne es verdadera comida, mi sangre es verdadera bebida. El que come mi cuerpo y bebe mi sangre permanece en mí y yo en él.

Dice. Lo anterior es una metáfora, manifiesta la unión del discípulo con su maestro; este le promete todas las bondades de su reino, mientras que aquel cree en lo que se le promete. Los fieles no logran identificar quién les habla, la habilidad de la oratoria del sacerdote les hace creer que quien habla es el mismísimo Jesús de Nazaret. Luego, sale de los zapatos del Nazareno y exhorta a los creyentes a creer que Jesús nació del corazón de la madre, se hizo hombre en el seno virginal bendito de santa María, ocupó el primer corazón más bello, el corazón inmaculado de la madre, y él también se recrea. Este diálogo personal del presbítero dominico con Jesús es muy similar al diálogo que realiza el padre Álvaro de Jesús Puerta con la Señora, La Virgen, los primeros sábados de cada mes en Soracá, Boyacá (Uribe, 2009, pp. 85-87). Por eso, dile a la Virgen:

Bendita sea tu pureza y eternamente lo sea,

pues todo un Dios se recrea en tan graciosa belleza.

A Ti, celestial princesa, oh Virgen Sagrada María,

Yo te ofrezco en este día alma, vida y corazón.

Mírame con compasión, no me dejes, Madre mía.

Amén.

Los fieles repiten al unísono. De repente, la oración dejó de invocar el nombre de Jesús; ahora invoca a María, y los fieles repiten tras de él: "No me dejes, Madre mía, hasta morir en tu amor, que te lleve de la mano, que te tenga cerca de su corazón, que no te suelte, porque no te perderás, no te saldrás del camino. No caerás si ella te levanta con tu manto". Las imágenes de María y Jesús se alternan, emergen libremente; Jesús estuvo presente durante la eucaristía, mientras María, en cambio, apareció en las primeras horas de la mañana, pero los dos se hacen fuertes en horas de la tarde, durante la liberación y la sanación, unificados por la fuerza de la oración.

Los gritos no se hacen esperar; son sonidos guturales, cavernosos, que provienen de la parte de atrás de la cortinita. Entre tanto, el padre se mueve por toda la ermita, y les recuerda a los fieles que no se asusten: "Estamos en presencia de 
María y Jesús". Luego, reza un avemaría, y los fieles lo hacen con él. De repente, una mujer empieza a temblar con movimientos impropios: mueve su cabeza de un lado para otro, alborotando su frondosa cabellera, y emite unos sonidos sobrenaturales. Estos parecen provenir de un volcán en erupción.

Al ver esto, el padre reza con más fortaleza, y los fieles también. Luego, se dirige hasta donde está la mujer, sin dejar de orar el avemaría, que se dirige hacia la humanidad de la mujer. Su guardia personal sale en su ayuda y la rodean; uno de ellos, con el puño cerrado, chuza a la mujer en el costado derecho, mientras esta suplica que la dejen en paz. Pero no es su voz la que suplica.

La guardia personal rodea a la mujer; uno de ellos le exige que diga quien está en su cuerpo, pero la mujer se resiste a responder. El padre Pacho, entre tanto, sigue orando, también muy cerca de ella, y exhorta a los fieles a que lo acompañen en su oración. Los miembros de la guardia personal tocan a la mujer y adquieren los mismos movimientos impropios, producen sonidos sobrenaturales, y la mujer se desploma. Queda inconsciente. Finalmente, la guardia personal y el padre Pacho se hunden detrás de la cortina y siguen emitiendo los sonidos. A medida que los sonidos desaparecen de la ermita, la mujer que yacía tumbada, despacio, cobra la conciencia. Son las 3:30 p. m.

\section{Iglesia y carismatismo católico}

Con los hombres de adarga, yelmo y espada, llegaron a nuestra América los misioneros católicos. Los registros señalan que fue Alonso de Ojeda quien lideró, en 1499, la expedición que condujo al primer europeo a colocar la planta de sus pies en suelo colombiano. Lo hizo en la península de la Guajira, pero solo hasta 1510, con la fundación de Santa María la Antigua del Darién, al norte del actual departamento del Chocó, fue que los frailes dominicos, franciscanos y agustinos dieron origen al proceso de evangelización más grande de la historia humana. Los "pueblos originarios" fueron testigos de la transformación de su universo religioso; diversidad de corrientes religiosas y nuevas espiritualidades se mezclaron con las autóctonas, y configuraron un mosaico muy variado y complejo, animado por una dinámica de cambio sin precedentes (Tejeiro, 2007, pp. 29-30).

Eliminar las creencias de los pueblos originarios para la convertirlos a la religión católica fue el principal objetivo de las primeras órdenes religiosas que pusieron sus pies en suelo colombiano. Aunque un número muy alto de aborígenes se resistió a la evangelización, con el tiempo, el catolicismo se arraigó en la población, con sus rituales religiosos y formas de celebración de cultos, y adquirió características propias (Tejeiro, 2007, 29-31). Luego, los misioneros dominicos, franciscanos y agustinos aprendieron las lenguas autóctonas, recogieron información sobre las 
costumbres de estos pueblos, e iniciaron la construcción de su acervo cultural. Por último, eliminadas las creencias y aprendidas las lenguas originarias, transmitieron a los indígenas la cultura española y latina, y unificaron, a través de la fuerza, y bajo el signo de la religión católica y la lengua castellana, a toda la población (Yunis, 2006, pp. 102-105).

Fundar ciudades, a través del ímpetu de las espadas, para luego evangelizarlas fue la estrategia española en aquellos penosos años de la Conquista. La fundación de Santa Marta, en 1525, y de Cartagena, en 1533, trajo consigo, además de los dominicos y los jesuitas, a los franciscanos y a los agustinos, quienes, respaldados por el acero conquistador, implantaron su deidad en las cabezas aún vírgenes de los caribes, y, en algunos casos, servían de freno a los desmanes de los conquistadores. La estrategia se repitió a lo largo del territorio nacional.

Después del Concilio de Trento (1545-1563), llegaron los jesuitas. Estos, a diferencia de las otras órdenes, se preocuparon por la educación de los pueblos originarios, no usaron la fuerza contra ellos, y se interesaron por su desarrollo, para que pudieran competir en igualdad de condiciones con los peninsulares. Después de 1600, llegaron los capuchinos, las carmelitas, los benedictinos, los hermanos hospitalarios de san Juan de Dios y los betlemitas. Entre las órdenes religiosas femeninas, también hicieron su arribo las clarisas, las agustinas, las carmelitas y las franciscanas. La evangelización y su corolario, la Iglesia, fueron los aparatos ideológicos de la dominación española, y los instrumentos para organizar la explotación económica al servicio del imperio español.

Durante la Colonia, y hasta mediados del siglo XX, la Iglesia fue la institución más poderosa. Su poder era evidente en todas las esferas del Virreinato de la Nueva Granada, pues tenía injerencia en la política, la economía, la educación y la cultura, e incluso en la vida privada de los colombianos (Beltrán, 2013, pp. 58-59). La cultura occidental entró en la vida de los "nativos" desde los conventos, las escuelas, los Colegios y las universidades, en cabeza de los frailes dominicos, jesuitas, franciscanos y agustinos, haciendo de la Iglesia la principal institución educadora, de entre todas aquellas que llegaron en galeones y carabelas, a finales del siglo XV. La guerra por la Independencia alineó a los misioneros católicos: la gran mayoría defendió las banderas de los ibéricos, y solo una pequeña minoría acompañó la causa patriota, curiosamente engendrada en el Colegio Mayor del Rosario y en el Colegio de San Bartolomé.

A mediados del siglo XIX, se implementaron en el país un conjunto de reformas liberales, con el fin de diezmar el poder de la Iglesia. Las logias francmasonas, las nacientes y escasas comunidades protestantes, las universidades públicas y las universidades liberales (Beltrán, 2013, pp. 59-60) pretendían, entre otras, arrebatarle su monopolio. Pero no fue sino hasta 1863-1886, con los liberales radicales en el poder, que la Iglesia sufrió los golpes más fuertes - la expropiación de sus 
bienes fue la expresión más notable de ello-. Sin embargo, la Iglesia resistió los embates de los radicales y logró que en la Constitución Política de 1886, Dios fuera la fuente suprema de toda autoridad en el país (Cifuentes, 2007, pp. 368-369).

Desde 1950, el poder de la Iglesia católica empezó a erosionarse. El periodo llamado Violencia Clásica (1948-1958) desencadenó una serie de situaciones que trasformaron el orden social, político, económico y cultural del país. La violencia de esta década tuvo como escenario natural los campos y el sector rural, por lo que originó un desplazamiento forzado hacia las grandes capitales. Esta explosión demográfica terminó por minar el control que ejercía la Iglesia, pues un número muy grande de sus correligionarios se concentraba, desde la Colonia, en el sector rural. Así empezaron a debilitarse, en el campo, aquellas viejas estructuras coloniales, como los sistemas comunitarios tradicionales, entre ellos, el compadrazgo.

Beltrán (2013) cree que el desvanecimiento del poder supremo de la Iglesia obedeció a dos causas: la secularización y la modernización excluyente por la que optó el país a mediados del siglo XX. El proceso de secularización, largo y tortuoso, terminó con una profunda diferenciación social en Colombia, motivada por políticas gubernamentales cuyo objetivo era insertar al país en las órbitas de los mercados internacionales (2013, p. 60). Para Beltrán, medidas como incentivar la industrialización, el auge de los medios de comunicación y la construcción de vías, la apertura a nuevos mercados y la inversión en infraestructura sirvieron como acicate para burocratizar la sociedad. Además, la urbanización acelerada de las ciudades colombianas, a mediados del siglo pasado, debilitó el control sobre las mentalidades y espiritualidades católicas de las personas que abandonaban los campos, lugar donde la Iglesia afianzaba la fe y todo su poder. Hubo, entonces, según Beltrán, una crisis de las vocaciones sacerdotales católicas a finales de la década de los cincuenta, lo que hizo que la Iglesia no contara con el número de sacerdotes suficientes para atender la demanda religiosa de las nacientes multitudes urbanas.

Con la modernización del país, aparecieron la radio y la televisión. La difusión de ideas opuestas y contrarias a las que profesó la Iglesia desde siempre abrió una grieta, pues la circulación de nuevas perspectivas religiosas terminó con el resquebrajamiento de la fe que los desplazados habían traído a las grandes urbes. De esta manera, se inició una diáspora, por donde empezó a escaparse el arraigo y la identidad que muchas personas venidas del campo aún sentían por la fe católica. La sensación de no pertenecer a ningún lado obligó a las masas a construir identidad alrededor de nuevas congregaciones religiosas, diferentes de la católica: adventistas, testigos de Jehová y el movimiento evangélico pentecostal, que desde finales del siglo XX ha demostrado ser el único rival en capacidad de disputarle a la Iglesia católica el liderazgo en el campo religioso colombiano (2013, pp. 60-61). Lo que no lograron los liberales reformadores de mediados del 
siglo XIX, ni los radicales en el tercer cuarto de este siglo, lo estaban logrando otras órdenes religiosas más flexibles y menos jerarquizadas.

La estructura jerárquica y rígida de la Iglesia católica se enfrentó a nuevas ofertas de fe, más flexibles, armoniosas y comunitarias a la usanza de los ágapes judíos de los primeros siglos del cristianismo. Así, según Beltrán, el proceso de secularización, urbanización y modernización que inició el Estado a mediados del siglo XX minó el poder supremo de la Iglesia, que vio cómo miles de feligreses abandonaron el seno católico que, luego, se expresó en lo que la sociología de las religiones ha denominado "pluralismo religioso".

Durante el Frente Nacional (1958-1974), mientras el bipartidismo lograba bajar los índices de violencia, la Iglesia se enfrentaba al auge de los nuevos movimientos religiosos y a la pérdida masiva de fieles. La apertura a las nuevas ideas que emergían en el seno de la Guerra Fría, y a las que estaban expuestas las masas, les permitieron a las personas entrar en contacto con actores e ideas que se escapaban del dominio de la Iglesia. Después del Frente Nacional, el interés de la Conferencia Episcopal, inspirada en el Concilio Vaticano II, era frenar el avance de la secularización y los nuevos movimientos religiosos, auspicio de los feligreses que habían abandonado las toldas católicas.

Pero lo que sucedió en Colombia con la Iglesia no fue más que una expresión de lo que acontecía en el moderno occidente cristiano. Las nuevas vertientes cristianas y protestantes enmarcadas dentro del avance de la economía mundial de bienes simbólicos (Ospina, 2007, pp. 392-393) desnudaron la oxidada y viciada jerarquía católica, que no tuvo otra opción que despabilarse para recuperar el rebaño perdido. El Concilio Vaticano II, surgido a mediados de la década de los sesenta, tenía como fin recuperar el rebaño a través de la adecuación dogmática del catolicismo. Para ello, el papa Juan XXIII hizo que el Concilio dialogara con otros movimientos religiosos, entre los que sobresalen algunos movimientos protestantes que albergaban a los disidentes católicos en todo el mundo. También sirvió para que algunos movimientos católicos tuvieran la aceptación oficial de la Iglesia, entre los que se destaca el de la Renovación Carismática Católica. La renovación se caracteriza por una intención de "avivamiento" en el ritual y en el dogma de fe, a través de la oración suplicante, el evangelismo, la reunión reiterada en pequeñas comunidades de fe, la entusiasta expresión corporal que se motiva en los ritos y el compromiso cristiano personal (Ospina, 2007, p. 393-394).

La Renovación Carismática tiene como principal estandarte al Espíritu Santo, y su misión es otorgar poderes y dones espirituales a quien invoque su presencia. Desde 1966 hasta el día de hoy, la campaña de la Iglesia para recuperar el rebaño perdido es con el retorno a emblemas perdidos en el tiempo, como la imagen del Espíritu Santo, Jesucristo - resucitado y vivo- y la comunidad cristiana primitiva. 
Ahora bien, fray Luis Francisco Pardo O. P. posee uno de los dones del Espíritu Santo, el don de sanar, o por lo menos así lo creen sus feligreses. Fue algo que adquirió con la sola formación sacerdotal, como lo creyó desde el día en el que monseñor Alfonso Uribe Jaramillo le dijo, en La Ceja, en el marco del retiro espiritual al cual asistió en 1986, las siguientes palabras: "Todo sacerdote tiene la gracia del Espíritu Santo para sanar y liberar a los oprimidos".

Ahora bien, el carisma del padre Pacho no aparece en momentos efímeros o de forma extravagante (Geertz, 1994, pp. 150-151), está presente en su vida diaria. Es una emoción que aparece para los fieles desde el martes, con la imposición de las manos; sigue el jueves, cuando los recibe e inicia con ellos la oración, y se magnifica el sábado, en la ermita. Cuando pasea por todo el lugar, como buscando algo, está reconociendo a los fieles que lo han visitado durante la semana, además de identificar los signos por los cuales se manifiesta el Maligno. Aunque no existe una cualidad única carismática, pues muchos hombres de distintas actividades la poseen - reyes, músicos, políticos, etc.-, lo cierto es que los feligreses que asisten a la ermita del Colegio Jordán de Sajonia creen que el padre Pacho posee el don de sanar. Los gritos, llantos, temblores extremos, voces guturales sobrenaturales, desmayos, entre otros, son expresiones de tal aseveración. El carisma del padre Pacho está en el centro mismo de las cosas, no subyace en ningún centro geográfico ni geométrico (Geertz, 1994, p. 152), sino que es un signo de atracción magnética que está en el corazón de la sanación y liberación demoníaca.

\section{Contaminación, cura y sanación}

El verbo contaminar posee muchas acepciones. La primera de las que aparecen en el diccionario de la Real Academia Española se refiere a la idea de alterar nocivamente la pureza o las condiciones normales de una cosa a través de agentes físicos o químicos; otra hace mención a la idea de profanar o quebrantar la Ley de Dios. De antiguo, existe en los hombres la preocupación por la higiene; esta se ve comprometida por agentes externos que desestabilizan lo estable, desordenan lo ordenado, pues la idea que tenemos de suciedad está vinculada a la existencia de organismos patógenos. Con ello, se entiende que la idea de suciedad es el resultado de una construcción simbólica, de un sistema ordenado y del rechazo a elementos inapropiados, por lo cual nuestra noción de contaminación es el rechazo a todo lo que implique desorden (Douglas, 1973, pp. 43-45).

La contaminación quebranta el orden. Los enfermos que asisten a la ermita del Colegio Jordán de Sajonia sufren, algo perturba su tranquilidad, su quietud, están contaminados. Existe una fuerza externa que se ha apropiado de ellos, no es física 


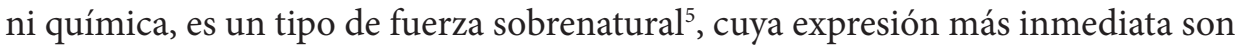
los movimientos impropios o las voces cavernosas que salen de los enfermos en la ermita. Aquellos están contaminados por una fuerza misteriosa, que hace las veces de un agente patógeno; de allí la necesidad de una cura. El padre Pacho los puede sanar - por lo menos, así lo creen ellos.

Ahora bien, dicen que en Grecia existió Quirón, un centauro inmortal, sabio, inteligente y fraterno que poseía el arte de curar. Apolo, amigo personal de Quirón, le confirió a este la educación de su hijo Asclepio, dios de la medicina. Asclepio aprendió de su mentor el don de la curación, conoció la vegetación y las plantas medicinales, y fue venerado en múltiples santuarios y templos griegos. El más importante de estos fue el templo de Epidauros, en el Peloponeso, donde eran llevados los enfermos para ser curados a través de ritos y prácticas mágico-religiosas. Dicen también que la familia de Hipócrates descendía de Asclepio, por lo que se cree que la práctica médica más antigua estuvo en manos de los sacerdotes. Alrededor de los templos del dios curador empezaron a aparecer unas escuelas de médicos laicos que ejercían el oficio, pero ya distanciados de los ritos mágico-religiosos de los asclépidas, con lo que definieron el carácter científico de la medicina que hasta hoy posee (Reale y Antíseri, 2007, pp. 71-72). Sin embargo, aunque el padre Pacho sana a los enfermos en la ermita del Colegio Jordán de Sajonia, como también lo hace Quirón en la Grecia mítica, lo cierto es que las funciones curativas del uno y del otro crean la diferencia. El padre sana las almas, mientras que Quirón hace lo mismo, pero con los cuerpos de los enfermos.

La voz cura proviene del latín curare, es decir, 'cuidado'. En 1330, se empezó a identificar al párroco con esta denominación, y, desde entonces, su asignación tiene que ver con la asistencia que presta a los enfermos. Por lo tanto, una de las misiones encomendadas a los sacerdotes era la de prestar asistencia a los enfermos, concretamente al cuidado espiritual de estos - vale decir que tiene a cargo curar las almas de sus feligreses-.

El poder de curar que posee el padre Pacho está asociado con principios mágicos primitivos: sanar y curar a los enfermos de la presencia de espíritus malignos. Así lo creen él, los endemoniados y todos los que asisten a su ermita. En este mismo horizonte de interpretación se encuentra Leví-Strauss, quien afirma que para que el brujo, sanador o curador, logre tal poder sobre los que cura, así como sobre el resto de los miembros de la comunidad, debe cumplir tres cualidades. Para el antropólogo francés, el individuo enfermo debe estar consciente de que realmente lo está, y, para que pueda sanarse, debe creer en el poder de la magia, es decir, en la eficacia de esta para sanarlo. Por ello, propone, en primer lugar, la

5 Lo sobrenatural, afirma Durkheim (1982), es una noción que caracteriza a todo lo que es religioso. Reconoce que se entiende por sobrenatural todas aquellas cosas que se escapan de nuestro entendimiento, pues es el mundo del misterio, de lo incognoscible, de lo incomprensible (pp. 42-43). 
necesidad de que el hechicero crea en la eficacia de sus técnicas; luego, la creencia del enfermo en que este lo puede curar, y, por último, la confianza de la opinión colectiva, través de la cual gravitan las relaciones entre el brujo y aquellos a quienes sana (Leví-Strauss, 1983, pp. 83-84).

El poder curativo de la palabra es de vieja data. La medicina griega primitiva, la filosofía platónica, el Nuevo Testamento y Clemente de Alejandría, en el siglo II d. C., se han referido al tratamiento de las aflicciones del cuerpo y del alma a través de esta. Después de superar las cualidades mágico-religiosas evidentes en la Grecia arcaica, la medicina se laiciza y se vuelve del dominio de la retórica sofista. De esta manera, hombres de otras profesiones distintas de la médica debatían, oraban y realizaban conferencias acerca de temas médicos. Hipócrates, en su Ley, creía que hay cosas sagradas que solo pueden ser reveladas a hombres sagrados. El carisma es una de esas cosas sagradas que posee el padre Pacho, pero que para Hipócrates solo eran reveladas a aquellos que se instruían en el misterio de la medicina. Hipócrates establece la primera relación entre el médico y el sabio. Esta síntesis sirve como acicate, no solo para entender el poder sanador de la palabra, sino también para comprender la relación tan cercana entre le medicina y el oficio que desempeña el padre Pacho todos los sábados en la pequeña ermita. A los médicos, desde la concepción de Hipócrates, se les ha revelado el poder de sanar a través de la medicina, en tanto que al padre Pacho, se le ha otorgado a través de su carisma.

Platón encuentra una relación directa entre el cuerpo sano y la educación de este. La capacidad de persuadir al enfermo la obtiene el médico, a través de su vínculo con la retórica, lo cual se observa en El banquete. En los labios del médico Erixímaco, Platón deja ver la capacidad del arte médico: curar y argumentar. Erixímaco le sugiere a Aristófanes algunos tratamientos para su hipo, mientras argumenta sobre la presencia de Eros en las cuestiones médicas. En el rito de sanación y liberación, el padre Pacho, al colocarse en los zapatos de Jesús, es decir, al hablar como si el que estuviera hablando fuera el mismísimo Jesús de Nazaret, además de asumir la función de cura para el alma, se convierte en un buen orador, teje plegarias con oraciones dirigidas al Nazareno, María y los ángeles. El padre Pacho es como Erixímaco, pero en vez de curar el hipo de Aristófanes, cura las aflicciones del alma de sus feligreses, a través de la oratoria.

En el Nuevo Testamento, Jesús adquiere la nominación de médico en la medida que cura el alma. En los evangelios de Marcos, Mateo, Juan y los Hechos de los Apóstoles, subyacen los milagros y las curaciones que el Nazareno hubo de realizar. Estas aparecen cuidadosamente señaladas en Ángeles y demonios por monseñor Alfonso Uribe Jaramillo; de aquí la alusión constante al poder sanador y curador de Jesús, al cual hace mención el padre Pacho en su rito. Las distintas sanaciones realizadas por Jesucristo van acompañadas de la oración y alabanzas al Todopoderoso; es decir, están rodeadas de un poder silábico que se adentra en el 
alma de los enfermos sin incisión alguna. Las curaciones y sanaciones de Jesús son señales del poder divino, sanador y curador de la palabra. El padre Pacho también cura con sus oraciones, es decir, lo hace con la fuerza de su voz anciana.

El paso de la filosofía griega a la filosofía cristiana se hizo a través de la palabra. La virtud en el cuidado del cuerpo y del alma que ambas profesan solo puede hacerse a través de la palabra; así lo expresa la obra de Clemente de Alejandría. "La palabra adquiere la función de sanar y salvar, luego de persuadir a los hombres hacia el abandono de los hábitos paganos, la adopción de las costumbres cristianas y el adiestramiento en el ejercicio gnóstico" (Druille, 2009, pp. 22-23). Como Cristo y los apóstoles, el padre Pacho cura con palabras, pues el único contacto físico con los enfermos es solo para ungirlos; el padre habla, ora, suplica y pide con sus palabras. Así lo testimonian la guardia personal del padre y algunos feligreses con quienes tuve oportunidad de hablar aquel 27 de septiembre de 2014 . Siempre lo hace durante todo el rito, pues él también está ungido por la gracia del Espíritu Santo para sanar, curar y liberar. En últimas, aunque la trinidad Madre, Hijo y Espíritu Santo son símbolos centrales en el rito carismático católico, no es solo la presencia de estos símbolos per sé la que cura, sana o libera, sino es la palabra curativa que se dinamiza a través de estos la que realiza la sanación.

\section{Referencias}

Beltrán, W. (2013). Pluralización religiosa y cambio social en Colombia. Bogotá: Pontificia Universidad Javeriana.

Cifuentes, M. T., (2007). Pluralismo en el catolicismo actual. En Creer y poder hoy (pp. 363-375). Bogotá: Universidad Nacional de Colombia.

De Aquino, T. (1993). The Aquinas prayer book. Manchester, NH: Sophia Institute Press.

Douglas, M. (1973). Pureza y peligro. Un análisis de los conceptos de contaminación y tabú. Madrid: Siglo Veintiuno.

Druille, P. (2009). El poder sanador de la palabra en Clemente de Alejandría. Recuperado de file://C:/Users/cliente/Desktop/el\%20poder\%20 de\%20la\%20palabra\%20(1).pdf

Durkheim, E. (1982). Las formas elementales de la vida religiosa: el sistema totémico en Australia. Madrid: Akal.

Geertz, C. (1994). Conocimiento local: ensayos sobre la interpretación de las culturas. Barcelona: Paidós. 
Leví-Strauss, C. (1983). Antropología estructural (vol. 1). Buenos Aires: Siglo Veintiuno.

Mauss, M. (2009). Ensayo sobre el don. Madrid: Katz.

Ospina, M. A. (2007). La renovación carismática católica: una fuente contemporánea de la eterna juventud. En Creer y poder hoy (pp. 389-410). Bogotá: Universidad Nacional de Colombia.

Reale, G. y Antíseri, D. (2010). Historia de la filosofía. Bogotá: San Pablo.

Tejeiro, C. (2007). La investigación social del fenómeno religioso en Colombia. En Creer y poder hoy (pp. 29-60). Bogotá: Universidad Nacional de Colombia.

Uribe, A. (1995). Ángeles y demonios. Buenos Aires: Lumen.

Uribe, C. A. (2009) Ante el santuario de la esperanza: imágenes que curan en Soracá, Boyacá, Colombia. Recuperado de $<$ http://www.redalyc.org/articulo.oa?id=35112428005>

Yunis, E. (2006). ¡Somos así! Bogotá: Bruna. 